The Geneva Papers on Risk and Insurance, 21 (No. 80, July 1996) 421-429

\title{
The Role of Risk Management and Insurance : Looking Beyond the Neo-classical Views on the Economics of Uncertainty
}

\author{
by Orio Giarini*
}

\section{Introduction}

At the Geneva Association for over two decades we have maintained that insurance and risk management have moved center-stage of the modern economy. The growth of insurance world-wide and its manifestly increasing relevance to key aspects of government action, (i.e. social policies, savings, environmental and industrial risks, health schemes, liability issues, catastrophic and systemic risks etc.) provide a clear indication of where some key issues in the modern economy are to be found.

And yet, the role of insurance and risk management is still grossly under-rated and students in economics in universities everywhere receive no basic education in this area. Insurance and risk management activities are as significant for the contemporary service economy as the textile industry was at the beginning of the industrial revolution. Clearly, some new advances in economic thinking have to take place and perhaps time is today ripe to re-evaluate and re-discuss the very roots of economic analysis, particularly at the macroeconomic level.

The ideas we shall be outlining here were the fruit of practical experience with marketing, strategic analysis and research mainly within the chemical industry and were already part of the working hypothesis behind the founding of the Geneva Association 23 years ago. They have also matured thanks to continuous research practice and university teaching over 20 years.

\section{Insurance in the industrial revolution}

In the course of the two centuries of the industrial revolution, manufacturing was the obvious top priority. Services were considered as a separate type of activity, not essential and in any case of secondary importance only.

Philosophically, economic theory itself was based on a deterministic scheme of thought dominated by price equilibrium. Such equilibrium was and still is largely felt to be certain. Where in practice uncertainty could no longer be discounted, the dominant philosophical

\footnotetext{
* Secretary General of the Geneva Association and Associate Professor of Economics at the University of Geneva.
} 
response was to suggest that it stemmed from a transient situation : it was inadequate information that made the price situation uncertain, a state of affairs that was said to be due to insufficient scientific progress. With time, science would eliminate such uncertainties making the price-equilibrium model an achievable goal. In other words, uncertainty was equated with ignorance and the faith underlying the deterministic philosophies deemed the giving of serious attention to what were considered to be "imperfections" of the social and economic system.

It should also be recognised that there is an important school in neo-classical contemporary economics which has devoted much research to the subject of uncertainty, due to "imperfect" or sometimes to "asymmetric" information.

Although this neo-classical school of economic thinking has made a major contribution to the study of certain aspects of modern insurance and risk-management, its essential limit today lies in the fact that uncertainty does not pertain to a transient state of imperfect knowledge but, as defined by indeterministic philosophy, (i.e. Karl Popper or Ilya Prigogyne) is an inevitable fact of life and theory. When one accepts, that all economic facts evolve in real, continuous time, one realises that as soon as any future event is included in any present economic analysis, the resulting model can only be, and will always be, a function of probability from which certainty is by definition excluded.

Therefore the first real issue in the battle to achieve adequate consideration for insurance activities as key economic activities, is progressively to effect a switch of a philosophical reference from deterministic to indeterministic models. A phenomenon, by the way, which took place in the hard sciences over 60 years ago.

Of course the problem is not exclusively philosophical and intellectual in nature: the search for certainty as a tool for regulating society has important implications for political ideologies. The problem is that the most uncertain thing in life and history is certainty and that, therefore, the soundest course for managing life and its problems would be to accept the fact of uncertainty and to treat it as a source of opportunity.

In contrast to the hard sciences where the transition proved to be relatively unproblematic, it is immediately apparent in the field of social science how difficult and delicate a task it is to effect such a fundamental switch in underlying philosophy.

But this also shows how deeply embedded in the social tissue of our times is the debate on the economic and social role of insurance and how fundamental and real are the issues it opens up.

\section{The emergence of the service economy}

We have already mentioned the fact that economics, as it emerged as a new doctrine following the development of the industrial revolution, started by considering services a secondary type of "product". Although, many economists would today admit that services are much more important than they were in the past, the mainstream economic thinking still revolves around the three-sectors theory: namely that economic activities are divided into three main sectors, i.e., agriculture, manufacturing and services. According to this theory, services as such are deemed to constitute a sector - the tertiary sector. The theory is still alive when, for example, it is applied to the negociation on services as has been carried out in the World Trade Organisation (formerly, the GATT). Indeed it is still fairly common to 
come across economic articles which speak of the problem of "de-industrialisation" as if services as they are developed were in the process of undermining industrial development. Today such considerations are, in our view, wholly inappropriate, not to say misguided.

In fact services no longer constitute a sector. They are rather functions which dominate almost every concievable type of agricultural and manufacturing activity. A good manufacturing industry is one that has internalized and developed services to the point where they become optimally efficient and competitive and this is especially important since service functions within the average modern manufacturing enterprise account for $70-80 \%$ of all costs. Factual analysis and figures demonstrate this contention beyond all doubt. It is, moreover, self-evident to anybody actually working in any of the so-called manufacturing industries (chemical, electrical, food, mechanical, etc.).

In other words the future image and role of insurance is also linked to our broader understanding of services as a key function in the modern "post-industrial" or "service" economy.

But at this point we find that traditional economic theories have set another barrier.

\section{The notion of value in classical and neo-classical economics and in the service economy}

It is worthwhile remembering that classical economics (indeed economics as a new discipline) was founded after the beginning of the industrial revolution by a moral philosopher (Adam Smith) searching for the most efficient methods (manufacturing, industrialization) of combatting poverty and hunger. In a world of scarce resources, manufacturing industry and remunerated work became the priorities. Work itself was the prime source of economic value and as such became the key to economic thinking up to the beginning of our century (supply-side economics).

Then, as the economist Joan Robinson has written, neo-classical economics "swept out the labour theory and utility came in. It is quality in commodities, it is argued, that makes individuals want to buy them, and the fact that individuals want to buy commodities shows that the latter have utility". Economics then became demand-side oriented. The key economists and decisive leaders of this evolution were Keynes and John Hicks. There were practical and historical reasons for this change, such as the 150 -year experience of economic crisis because of over-production and deflation (for lack of solvable monetized demand). This is where Keynes and Keynesian ideas played a decisive role. They presupposed sufficient elasticity on the demand side to stimulate and regulate the economy up to the so-called full employment of resources (capital and labour).

John Hicks was to influence more the culture and ideology of the other major school of economics known today as monetarism. It is his subjective theory of value that lied behind what Milton Freedman was later to call "the freedom to choose". It has also served as the basis for the thinking of the free trader and free markets schools (including by the way the so-called supply siders linked to the modern Chicago school). But in fact the impact of Hicks and his followers in the modern world has also been largely conditioned by ideological necessity: classical economics as developed by Adam Smith, which placed the notions of supply and work center-stage as the definition of economic value, were in a sense taken over by Karl Marx and the Marxist economists to such an extent that liberal antiMarxist economists had some difficulty in finding a theoretical legitimacy for their views. This is where John Hicks was extremely important. But it also explains why it was necessary 
to adopt a demand-side notion of value in order to properly defend the notion of a free market. In short, the deterministic vision of economic equilibrium had played a trick and, on the very basis of the notion of value, has captured to the benefit of the Marxists the fundamental good sense of many of Adam Smith's ideas.

But herein also we find the roots and reasons why modern economic theory has some difficulty in understanding the role played by services, for were the environment and the incredible increase in service functions in the manufacturing system to be adequately accounted for, economic theory would have to pay much greater attention to what is happening on the supply side. From the demand-side point of view, what matters at the end of the day is not how services, products or similar activities are produced but the fact that there is somebody out there willing to purchase them.

The point is, however, that change in the structure of production has modified the conditions for supply elasticities.

Historically the turning point was the occasion of the oil crisis in 1973. This was at first considered an accidental and transient economic phenomenon. Computer models were saying that even if the price of oil was increasing rapidly, it still only counted for $1 \%$ of the total increase in manufacturing costs across the economy as a whole.

On the contrary, the crisis was indicative of a situation in which supply, unexpectedly, was becoming increasingly rigid. Hence the situation of inflation that was not at first recognized as a structural problem and that only 10 to 12 years later has become accepted as a fundamental aspect of macro-economic strategy and policy. Hence, the increased autonomous development of central banks.

And now we can safely reconsider the supply side of the economic system, when we relate it to an undeterministic philosophy of reference.

\section{The new characteristics (and conditions of rigidity) of supply in the economy.}

It is recorded history that since 1973 the average growth rate of GNP in most industrialized countries has fallen from an average $6 \%$ to an average $2-3 \%$ per year.

The traditional notion of supply based mainly on pure manufacturing activities was, and to some extent still is considered by many as something which can be developed at will thanks to the extraordinary advance of both science and technology in our time. In its assertion about science and technology in our time registering progress unheared of in the past, the proposition is perfectly correct. However, it goes wildly wrong in its assumption that this development goes hand in hand with a continuing ability to make economic supply elastic at will. We described this phenomenon in a book which was published in English during the seventies*.

The facts about the new economic situation we need to keep in mind are the following:

- The increased importance of service functions within all manufacturing activities has modified the conditions and levels of economies of scale and productivity.

* "The Diminishing Returns of Technology", Pergamon Press, Orio Giarini and Henri Loubergé, Oxford, 1978. 
- The very fact of a growing number of products and systems being based on advanced technology and produced in much larger quantities requires increased investment in: distribution, education, capacity to use, utilization systems and finally also waste disposal. In other words, so-called production costs have increasingly been switched over to service functions relating to the use of products or systems during their very life-time of utilization and finally (this is the environmental problem) at the point at which they become waste and are destroyed or recycled.

- This phenomenon has meant that today, increasingly, pricing systems have come to resemble insurance policies and are moving away from the traditional simplified "industrial" price-fixing model. Prices increasingly reflect a probabilistic judgment about the future cost of utilization. Increasingly does management in "modern industry" require our learning about a key problem that insurers and risk managers have always had to face - how to fix prices so as to include future costs.

In addition, new major problems relating to vulnerability have arisen as a consequence of modern technology. The vulnerability we speak of has to do with a very precise notion in engineering. It does not mean at all that technology is on average of lesser quality than it was in the past. Quite the contrary. Vulnerability means that the more technologically advanced a system is, the narrower the acceptable margin of error in the way it functions. And the consequences of mismanagement or accident are very much greater. This is something with which insurers are familiar: the great problem in so many sectors of reduced frequency and increased gravity of damages. Which brings us to the fundamental notion of insurability and economics of scale, something we shall be looking at in the last section of these notes.

It is important to understand this issue correctly. Take for instance the horse and carriage as a mode of transport in the last century. It was very inefficient, broke down frequently but in fact in terms of the consequences of an accident was not all that vulnerable. An aeroplane on the other hand is very efficient, there are absolutely very few accidents affecting the enormous number of flights these days, but when accidents do occur they show how vulnerable the system really is. Control of this vulnerability explains both the growth of insurance in this and other sectors as well as the fundamental strategic importance of riskinanagement.

\section{From rigidity of supply to the birth of risk management}

All the above considerations are behind the birth and development of "industrial" risk management as a strategic issue for all sorts of economic and government activities. Insurance is an important part of risk management practice.

Risk management and insurance are now located at the core of many key social and economic problems for several reasons.

The first of these problems became apparent during the late sixties and early seventies. It concerned industrial vulnerability, especially in relation to environmental risks. The notion of liability also underwent fundamental change: and again, the reason for this change was not simply that fee-hungry American lawyers had suddenly hit upon a new and fashionable approach to the issue of liability. It has to do with the fact that the economy is now providing systems and products which are appreciated as to their functioning, their performance over their period of utilization and their results. This evolution of liability has 
been a key cathalyst in creating a new notion of demand which focusses not so much (as during the industrial revolution) on the purchase of products, as on the buying of performance (which is typical of the service economy). The Geneva Association, as early as 1974 conducted the first European survey into risk management practices and vulnerability issues within the European chemical industries. We then went on to study specific new vulnerabilities linked to the development of new technologies such as computer risks (our general study in this area was also a European first), risks related to transport by containerization, to the storing of liquefied natural gases, to superconductivity, etc.

On a more general level it was obvious that this phenomenon of increased vulnerabilities in production/manufacturing systems was becoming another important yard-stick for assessing the feasibility of new investment in new technologies. It increased the overall level of uncertainty relating to investment in many sectors and it is from there that new directions and impulses started to emerge (an instance is today's iron and steel industry) towards new modes of industrial development to cope with all sorts of production-system vulnerabilities based on dispersion rather than on concentration of production and distribution.

\section{From industrial vulnerability to vulnerability of social policies and social security}

Given these changes in the structure of, and conditions for, producing wealth, the so-called industrialized nations of the world have been struggling for the last twenty years to cope with an economic growth-rate of $2 \%$, in a world where $3 \%$ is now considered a great achievement.

This slower growth has begun to change the conditions for the feasibility of social security systems as they have been developed since the end of the Second World War.

The uncertain future of such social security systems has become increasingly apparent and here again in the 70s the Geneva Association pioneered some of the first studies in a number of European countries in its attempts to demonstrate that if rigidity in an economy's capacity to achieve higher growth persisted, then the time would come when State-provided social protection, if it were to survive, would require a growing contribution from complementary private schemes.

I still remember the days when, twenty years ago, a professor of life insurance in a wellknown university thought he had nothing to do with the professor of social security systems working in the same university only a few doors down from his own. The same at the time could also be said of practitioners in the insurance industry who were still a long way from realising that the development of social security was a key to developing their own market for life insurance and pension funds. The situation today hardly needs advertising since it ranks at the top of the list of current economic and social problems.

\section{Uncertainty and financial risk management}

1973 was also the year when the international monetary authorities decided to abandon the fixed exchange-rate system. At the same time inflation started soaring after a period of lower, creeping inflation. 
The mainstream economic community has taken some time to recognize that inflation was in fact a structural and not simply a cyclical problem. As a consequence, the central banks and monetary authorities took time to come to the conclusion that it was essential to reduce inflation to a minimum in order to avoid the economy going wildly astray.

But for many years, it was not recognized that something fundamentally new had occurred in the economy and so, for a while, the dominant policy of many governments during the seventies was to accept and even stimulate deficits and to rely on a future "normal" recovery (at $6 \%$ per year) to re-establish some sort of equilibrium. This never happened and all the major turmoils experienced in the industrialized countries during the seventies and into the eighties are largely due to this misjudgment.

In the meantime, the basic constituents of monetary uncertainty (inflation rates, interest rates, exchange rates) have started to modify the very nature of the banking system and to a large extent also the functioning of industrial companies. The latter began to realise that abrupt modifications in monetary conditions were in many cases having more impact on the profitability of their activities, than was their main industrial performance. A recent book has even shown that at the time of the speculation which forced the pound sterling and Italian lira out of the European monetary system, it was not just the performance of professional speculators which created pressure to destroy a large part of the European monetary system, but rather the role played by many other industrial and financial agents. And this in a situation in which traded currencies every day go beyond one trillion dollars worldwide.

The banks, following in industry's footsteps, were soon to begin talking about risk management, modifying fundamentally the role and conception they had of their own business and becoming involved in managing monetary risks as well as starting work on their own investment programs. The development of derivatives and other systems was the consequence of this situation. We are currently in the middle of this other gigantic wave in the global revolution of the economics of uncertainty and risk management, as a key feature of the global service economy.

The concept itself of risk management has become a common one also for the financial community.

\section{Decentralization and international integration}

In the service economy, an increasing part of the "production" process is being located where the "consumer" (prosumer) is to be found, particularly in respect of distribution, utilization and waste recycling. This has the effect of stimulating the application of the subsidiarity principle:

- At the local level, by re-envigorating the decentralisation process, particularly for all forms of productive activity. As in the case of insurance, it is becoming increasingly clear that the major part of "production" (including for instance claims handling) can only take place where the customers are. Therefore it is the establishment aspect of international economic integration which is now the key issue: The transfer of services across borders is adequate, or even feasible only where, whatever the activity, such establishment is locally rooted. 
- At the international level, it also becomes obvious that investment is no longer an alternative to trade but is complementary and even essential to trade itself even where the latter relates exclusively to material products. A cross-border telephone call is an international operation, but a local infrastructure is needed for both receiving and emitting the signals.

This, by the way, has changed considerably our perception of the world economic globalization process and it is only with some conceptual, not to mention political, difficulty that the new agreements on trade, for instance in the World Trade Organization, have been able to keep track of this reality.

Here again the experience of insurance largely matches the reality of an integrating global economy and the manner of this process.

\section{Insurability - a case-study in proposing a new foundation for economic analysis in determining a proper apportionment of public and private activities}

In the industrial economy there have been various formula for apportioning activities between the private and public sectors, the latter sector comprising those activities deemed to be in the "public interest".

Experience has shown that many "public" activities are often better managed privately. A key economic issue for efficiency is "moral hazard". What we have here is yet another fundamental cornerstone of the insurance business.

The State is supposed to intervene on purely political grounds within the accepted standards of social justice and levels of redistribution (both in space and time). This policy is, or should be, financed through the fiscal system.

In the service economy, State or social intervention is implicitly or explicitly needed when, in the production of economic performances, the private sector is found to be incapable of managing specific situations. This corresponds to what is defined, in the insurance sector, as the level of insurability.

Beyond that level which refers to a manageable combination and homogeneity of risk classes, frequency and gravity of events, private initiative cannot cope. For the upper levels of vulnerability of persons, communities and for all sorts of exposure (to events ranging from natural catastrophes to social security), which are not economically "insurable", the public authorities must step in.

Industrial and economic policies would then set as their priority objective the achieving of the highest possible level of insurability in all possible circumstances.

Beyond that, an understanding of the critical problem of insurability could be used as a powerful tool in stimulating an adequate economic understanding of the insurance business as a whole. Insurance today has a vested interest in having its modes of operation understood. This will be difficult to achieve in a world where the majority of students in economics do not even possess a rudimentary knowledge of insurance and where economic theory has for too long neglected the shift in focus to the supply side and basic changes in the notion and reality of uncertainty. 
In pursuing such lines of inquiry, insurance will not only be defending its own legitimate interests. As a sector it occupies a virtually unique position in the economy, for a proper understanding of its modes of operation will provide a model for our deeper understanding of the global interests of society at large. Although this will not make insurance activities per se any easier, it will tigger the fundamental change destined to alter the face and image of insurance over the next ten or so years.

For, as we said at the beginning, insurance is to the modern service economy what the textile industry was to the first industrial revolution. 